REFLECTIONS:

NEUROLOGY AND THE

HUMANITIES

Section Editor

Michael H. Brooke, MD

\section{A punder in Catch-22}

Christopher J. Hammond

Hubert H. Fernandez, MD

Michael S. Okun, MD

Address correspondence and reprint requests to Dr. Hubert $\mathrm{H}$. Fernandez, Department of Neurology, McKnight Brain Institute/University of Florida College of Medicine, PO Box 1000236, Gainesville, FL 32610 Fernandez@neurology.ufl.edu
There was only one catch, and that was Catch-22, which specified that a concern for one's safety in the face of dangers that were real and immediate was the process of a rational mind. Orr, a pilot and one of the main characters, was crazy and could be grounded. All he had to do was ask; and as soon as he did, he would no longer be crazy and he would have to fly more missions. Orr would be crazy to fly more missions and sane if he didn't, but if he was sane he had to fly them. If he flew them he was crazy and didn't have to, but if he didn't want to, he was sane and had to. Yossarian was moved very deeply by the absolute simplicity of this clause of "Catch-22" and let out a respectful whistle.

$$
\text { -Joseph Heller, Catch-22 }
$$

These words from Joseph Heller's dark and satirical novel have always stayed with us, reminding us of the vicious cycles that we get caught in as we proceed through our lives. The Oxford English Dictionary defines catch-22 as a "set of circumstances in which one requirement, etc., is dependent upon another, which is in turn dependent upon the first." Into his first novel, Heller interweaves a series of these circular dilemmas, and, in doing so, has placed himself into the pages of literary history. But is there something more to this novel_-does it provide an early example of a cyclic and pathologic behavior that might have a neurologic origin?

Catch-22 tells the story of World War II flier John Yossarian and his fellow lead bombardiers as they attempt to survive the war while living under the shadow of a catch-22. In chapter 3, titled Havermayer, Yossarian, the main character and one of the pilots, returns from the infirmary to find a fellow bombardier named Orr performing an odd behavior.

Orr, who, on the day Yossarian came back, was tinkering with the faucet that fed gasoline into the stove he had started building while Yossarian was in the hospital. "What are you doing?" Yossarian asked guardedly when he entered the tent, although he saw at once. "There's a leak here," Orr said. "I'm trying to fix it."

Orr was kneeling on the floor of the tent. He worked without pause, taking the faucet apart, spreading all the tiny pieces out carefully, counting and then studying each one interminably as though he had never seen anything remotely similar before, and then reassembling the whole small apparatus, over and over and over and over again, with no loss of patience or interest, no sign of fatigue, no indication of ever concluding.

There is a phenomenon in the neurology literature referred to as punding, which is very close in definition to the behaviors described in Heller's book. The term punding has been used to describe the prolonged and purposeless complex stereotypical motor behaviors of amphetamine abusers. Punding is characterized by an intense fascination with repetitive manipulation of technical or mechanical equipment, the continued handling, examining, and sorting of common objects, grooming, hoarding, abnormally increased writing, and even excessive nonsocially sanctioned dancing. The term punding comes from the amphetamine abusers themselves, who described their odd stereotyped behavior, which others have referred to as "being hung up," "pottering," or "knick knocking." Punding can also be translated from Swedish slang to mean "blockhead." Examples of punding behaviors include picking at oneself or taking apart watches and radios or sorting and arranging common objects such as lining up pebbles, rocks, or other small objects. Punding is probably best known from its description in patients with Parkinson disease who are being treated with dopamine agonists and L-dopa.

Orr's behavior during chapter 3 fits the current definition of punding as it is used in the neurology literature. When Yossarian returns from the infirmary, Orr is "hung up" in a purposeless complex behavior: taking apart a faucet, arranging the pieces, and putting it back together. In his description, Heller notes that Orr continues this perseverative behavior with no signs of fatigue, loss of interest, or indication of stopping. The literature has demonstrated that punders continue their behaviors for extended periods of time even to the point of urinating or defecating themselves instead of terminating the behavior. Another component of punding is that punders often lack insight into the bizarre and dysfunctional nature of their behaviors. When Yossarian approaches Orr and questions what he is doing and why, Orr responds that he is fixing a leak. This rationalization of his perseverative behavior has also been observed in some case reports of punding. Attempts to stop the stereotyped behaviors are in real life often met with resistance, irritability, and dysphoria from the punder. In Heller's novel, Yossarian, after asking Orr what he is doing and why he is doing it, elects to not attempt to stop Orr from continuing his perseverative behavior. While the novel does not directly address his reasoning, it is implied that Yossarian does not feel he will be effective in stopping the behaviors, and for this reason he chooses not to inter- 
fere as Orr continues dismantling and reassembling the faucet.

Punding was first described in the medical literature by Rylander et al. in 1972. Joseph Heller wrote Catch-22 in the early 1950s and it was first published in 1961, 11 years before Rylander's description. The thought must therefore cross one's mind when reading this book: Is what I am reading the first description of punding? Did Joseph Heller describe punding 11 years before Rylander? If we are to assume that Heller's character Orr represents, in actuality, the first case of punding, then this character would have to be based upon a real patient. Further exploration into Heller's own personal history may help to shed light on this issue.

In 1942, Joseph Heller joined the United States Army Air Corps. As a World War II bombardier, he flew 60 combat missions in B-25s over Northern Africa and Italy. While Heller did not intend his novel to be autobiographical in nature, he reported that much of his material came from his personal experiences as well as from the experiences of other friends who fought in World War II. The character of Orr was based upon a pilot named Edward Ritter, who was Joseph Heller's tent-mate during the war. Heller himself describes Ritter as "something of a tireless wonder as a handyman, one with unlimited patience who took pleasure in making and fixing things." Heller's description of Ritter is consistent with the intense fascination with and repetitive manipulation of technical, mechanical equipment that typifies punding, but it is unclear if Ritter's behaviors are pathologic in nature. Heller does not reveal a background that would provide us with a likely etiology for his character's punding, although the character was recovering from a closed head injury inflicted by the stiletto heel of a prostitute. Heller leaves much room for speculation as he reports, "it was on these qualities of his, his patient genius for building and fixing things and these recurring close calls in aerial combat, only on these, that I fashioned the character of Orr in Catch-22." While it is speculative and he does not use the term punding in his novel, Heller likely observed and later integrated a case of punding into Catch-22, 11 years before Rylander's description in the medical literature. We end this reflection with a question that is in the spirit of Catch-22. If Orr's punding-like behaviors were not based upon Ritter, then we are faced with a circular dilemma: Which came first, the literary or the medical observation of punding? 


\title{
Neurology
}

\author{
A punder in Catch-22 \\ Christopher J. Hammond, Hubert H. Fernandez and Michael S. Okun \\ Neurology 2009;72;574-575 \\ DOI 10.1212/01.wnl.0000342159.54977.82
}

This information is current as of February 9, 2009

\section{Updated Information \& Services}

Subspecialty Collections

Permissions \& Licensing

\section{Reprints}

including high resolution figures, can be found at: http://n.neurology.org/content/72/6/574.full

This article, along with others on similar topics, appears in the following collection(s):

All Neuropsychology/Behavior

http://n.neurology.org/cgi/collection/all_neuropsychology_behavior Brain trauma

http://n.neurology.org/cgi/collection/brain_trauma

Information about reproducing this article in parts (figures,tables) or in its entirety can be found online at:

http://www.neurology.org/about/about_the_journal\#permissions

Information about ordering reprints can be found online:

http://n.neurology.org/subscribers/advertise

Neurology ${ }^{\circledR}$ is the official journal of the American Academy of Neurology. Published continuously since 1951, it is now a weekly with 48 issues per year. Copyright. All rights reserved. Print ISSN: 0028-3878. Online ISSN: 1526-632X.

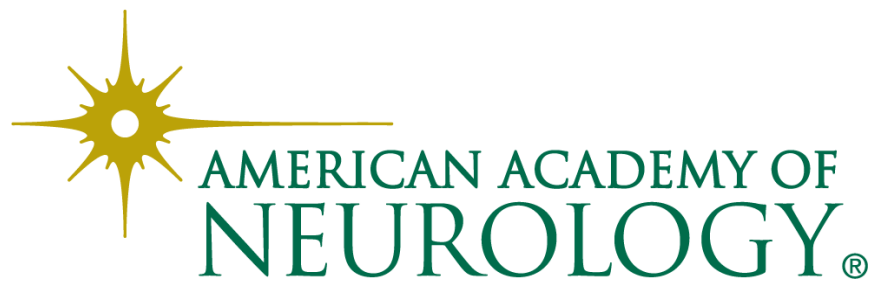

